\title{
Сучасні підходи до призначення радіойод- діагностики та радіойод- терапії хворим, прооперованим із приводу папілярної карциноми щитоподібної залози
}

\section{Б.Б. Гуда, \\ С.В. Гулеватий, М.Д. Тронько}

ДУ «Інститут ендокринології та обміну речовин ім. В.П. Комісаренка НАМН України»

\begin{abstract}
Резюме. Мета - обгрунтувати доцільність призначення радіойод-діагностики та радіойод-абляції пацієнтам із папілярними карциномами щитоподібної залози (Щз) із різних груп ризику. Матеріал і методи. Аналізували дані когорти хворих із папілярними карциномами ЩЗ, які отримували комбіноване лікування 1995-2014 роками (4 956 осіб), і хворих, яким було проведено радіойод-терапію після екстрафасціальної тиреоїдектомії 2018 року (98 осіб). Результати. Частота папілярних карцином Щ3 з агресивнішими характеристиками (великий розмір, наявність метастазування, інтра- або екстратиреоїдної інвазії, мультифокальності) та більш несприятливим перебігом (вища стадія хвороби та групи ризику, більша кількість курсів радіойод-терапії, несприятливий прогноз за MACIS) серед хворих когорти за 20 років спостереження зменшилася. У 71\% хворих із папілярною карциномою Щ3 категорії рT1-рT2N0M0 за результатами діагностичного сканування накопичення радіофармпрепарату було відсутнім або незначним. Висновки. Радикальне видалення Щ3 із пухлиною $є$ необхідною умовою для проведення хворим із папілярною карциномою Щз дуже низького та низького ризику лише радіойод-діагностики без подальшої процедури радіойод-абляції. Водночас, враховуючи українські реалії, цілком відмовитися від застосування абляції з використанням ${ }^{131}$ в в пацієнтів України, які входять до групи з низьким ризиком (що є сучасним трендом у світовій тиреодології), наразі не можна.
\end{abstract}

Ключові слова: папілярна карцинома, радіойод-діагностика, радіойод-абляція.

* Адреса для листування (Correspondence): ДУ «Інститут ендокринології та обміну речовин ім. В.П. Комісаренка НАМН України», вул. Вишгородська, 69, м. Київ, 04114

Україна. E-mail: zdovado@ukr.net 
Сучасні міжнародні рекомендації щодо лікування пацієнтів із диференційованим раком щитоподібної залози (ДРЩЗ) різняться та залишаються предметом постійних дебатів [1-4]. Водночас упродовж останніх років дедалі частіше з'являються думки, що лікування ДРЩЗ у пацієнтів із дуже низьким і низьким ризиком має бути набагато консервативнішим, із менш екстенсивною хірургією (або взагалі без хірургічного втручання), зменшенням використання радіоізотопів і менш інтенсивним спостереженням за хворими [5-8]. Так, за деякими висновками, лише 15-22\% пацієнтів із ДРЩЗ потребують радіойодного лікування [9], а за даними реєстру Каліфорнійського онкологічного центру, з 1999 по 2015 рік частота застосування абляції ${ }^{131}$ І знизилася на 20\% (з 67,4\% до 48,6\%) [10].

За сучасними протоколами, радіойод-терапію (РЙТ, абляційну та/або ад’ювантну) показано для пацієнтів із ДРЩЗ високого ризику (рT3-рТ4, будь-який N1, будь-який М1). У пацієнтів низького ризику (pT1b-pT2N0M0), а також для хворих із мікрокарциномами (карциноми з дуже низьким ризиком) радіойод-абляцію (РЙА) не проводять [1, 4, 11, 12]. У проспективних клінічних дослідженнях позитивні наслідки РЙТ продемонстровано лише в групі пацієнтів із високим ризиком рецидиву ДРЩЗ, тоді як у пацієнтів із дуже низьким ризиком позитивний ефект РЙТ щодо ймовірності виникнення рецидиву, а також щодо показників загального виживання пацієнтів не підтверджено: у таких пацієнтів і без проведення процедури абляції показники безрецидивного виживання наближено до 100\% [13, 14].

РЙА пацієнтам із низьким і дуже низьким ризиком показано лише у випадку наявності чинників ризику (мультифокальність, інфільтративний ріст пухлини, агресивні гістологічні варіанти папілярної карциноми, низький ступінь диференціювання, наявність мутацій $B R A F^{V 600 E}$ або одночасно мутацій $B R A F^{V 600 E}$ i $T E R T$, десмопластичний фіброз у позапухлинній тканині, зовнішнє опромінення шиї в анамнезі) [15-18]. Натомість у рекомендаціях Американської тиреоїдної асоціації (АТА) мультифокальність не є обов'язковим приводом для проведення РЙА [1].

Дискусійним залишається й питання термінів проведення РЙА. Оптимальним проміжком часу між операцією та першим призначенням радіоізотопу вважають 1-2 міс. [4, 13, 19, 20].
Виконання абляції раніше ніж за 21 добу після операції небажано, оскільки за такий термін не завжди можна досягти адекватного підняття рівня ТТГ, що необхідно для активації процесу захоплення радіонукліда тиреоїдними клітинами $[13,21]$. Відповідно до рекомендацій, такий рівень ТТГ може бути досягнуто через щонайменше 3 тижні після тиреоїдектомії або за 4-6 тижнів після припинення приймання тироксину $[1,2,4]$. Остаточно не визначеною є також ефективна доза радіофармпрепарату (РФП) для пацієнтів із низьким ризиком рецидивів - від 30 мКі до 100 мКі і навіть 200 мКі [1, 2, 4, 22]. Результати великих міжнаціональних рандомізованих досліджень засвідчили, що застосування меншої дози (30 мКі $\left.{ }^{131} \mathrm{I}\right)$ достатньо для отримання високої якості абляції тиреоїдного залишку, але з меншою кількістю гострих побічних ефектів опромінення [3, 23].

В Україні, зважаючи на значне зростання захворюваності на ДРЩЗ після радіаційного опромінення населення внаслідок аварії на ЧАЕС [24] із доведеним чинником радіогенної ініціації тиреоїдного канцерогенезу [25, 26], а також на існування підвищеного ризику виникнення тиреоїдних карцином, що не зменшується з часом, який минув після Чорнобильської катастрофи [27, 28], протокол лікування хворих iз різним ризиком передбачає обов'язкове виконання тотальної тиреоїдектомії та обов'язкове (!) проведення поопераційної РЙА (80-100 мКі $\left.{ }^{131} \mathrm{I}\right)$ i, за результатами радіойод-діагностики (РЙД, 5 мКi $\left.{ }^{131} \mathrm{I}\right)$, яку проводять пізніше, ад'ювантної РЙТ (100-150 мКі $\left.{ }^{131} \mathrm{I}\right)$ [19].

Слід зазначити, що із віддаленням від дати аварії та дорослішанням пацієнтів збільшується відсоток інкапсульованих пухлин, а також кількість мікрокарцином [27, 28]. В Україні щорічно збільшується число випадків менш агресивних карцином, що не завжди потребують лікування радіоактивним йодом. I хоча наявність в анамнезі пацієнта факту радіаційного опромінення (як і дитячий вік пацієнтів) розцінюють як показання для обов'язкової абляції [13, 29], результати тривалого спостереження за хворими з групи підвищеного ризику, яким було проведено органозберігаючі операції з приводу ДРЩЗ, свідчать про дуже невелику серед них кількість рецидивів [30].

Слід зазначити, що в клінічній практиці існують різні підходи до проведення РЙА. Перший 
передбачає виконання попереднього діагностичного тесту з наступним призначенням індивідуальної дози РФП. Другий - пацієнтам одразу призначають лікувальну дозу без попередньої діагностики. Перший підхід широко застосовується в Америці та, наприклад, у Північній Африці, другий - в Свропі, у тому числі в Україні [2, 19, 31]. Проведення перед абляцією попереднього сканування має низку переваг: можливість оцінки кількості залишкової тканини, виявлення раніше не виявлених метастазів і, отже, вибір адекватної тактики лікування [21, 31]. Для попереднього оцінювання об’єму залишкової тиреоїдної тканини використовують невисоку активність ${ }^{131}$ I (3-5 мКі) для уникнення stuning-ефекту [21].

Зважаючи на сучасні тенденції щодо зниження радіаційного навантаження на організм пацієнта під час радіойодного лікування хворих iз папілярними карциномами Щ3, а також на рекомендації АТА, Свропейської тиреоїдної асоціації, Європейської асоціації ядерної медицини, останніми роками в практиці ДУ «Інститут ендокринології та обміну речовин ім. В.П. Комісаренка НАМН України» (далі - Інститут) розв'язання питання про проведення РЙА грунтується на індивідуальному профілі ризику пацієнта. Аналіз отриманих даних та обгрунтування деяких змін до протоколу проведення РЙТ у практиці українських радіологів стало метою цієї роботи.

\section{Матеріал і методи}

Проведено ретроспективне дослідження когорти пацієнтів, оперованих із приводу папілярної карциноми ЩЗ в Інституті в період із 1995 по 2014 рік. Загальна кількість пацієнтів у когорті становила 4956 осіб. Аналізували такі показники для кожного пацієнта: вік на момент операції, дата народження, розміри та характеристика пухлини за TNM (використовували 7-му редакцію), клінічна стадія, група ризику, кількість балів за шкалою MACIS, кількість курсів радіойодного лікування. Вік хворих - від 7 до 85 років. У більшості випадків (4547 пацієнтів, 91,7\%) було виконано тиреоїдектомію, у 1086 (21,9\%) хворих доповнену дисекцією шиї; у 409 пацієнтів проведено органозберігаючі операції.

Для визначення динамічних змін у часі характеристик папілярних карцином ЩЗ (розмір, ка- тегорія TNM, інвазійні властивості тощо) та клінічних характеристик захворювання (стадія, група ризику, обсяг операції, кількість курсів РЙТ) пацієнтів розподілили на групи за датою проведення операції (п'ять 5-річних періодів). Аналіз доцільності призначення РЙД і РЙА в пацієнтів із різних груп ризику, яких було проліковано в Інституті 2018 року, проведено в групі з 98 осіб.

Статистичну обробку даних проводили з використанням критерію узгодженості розподілів $\chi^{2}$ Пірсона $\left(\mathrm{p}_{\chi_{2}}\right)$ і непараметричного критерію Вілкоксона - Манна - Уїтні $\left(\mathrm{p}_{\mathrm{u}}\right)$ із використанням пакета комп'ютерних програм Statistica 12 by StatSoft, Inc. Критичний рівень значущості приймали за 0,05.

\section{Результати та обговорення}

Від 1995 по 2014 рік змінилася структура поширеності папілярних карцином Щ3, які мають різний розмір: відсоток хворих із мікрокарциномами за 20 років спостереження збільшився в 3,5 раза (табл. 1) унаслідок поступового зменшення поширеності папілярних карцином ЩЗ розміром понад 20 мм: 51,8\% (294/568)$41,7 \%(421 / 1010)-32,3 \%(462 / 1432)-22,5 \%$ (437/1946), р<0,001 (для груп 1995-1999 рр., 2000-2004 pp., 2005-2009 рр., 2010-2014 рр. відповідно). Подібний характер змін зафіксовано за результатами аналізу поширеності папілярних карцином Щ3 категорії Т: прогресуюче з часом зростання відсотка хворих із пухлинами категорії Т1-Т2 (табл. 1) відбувалося на тлі зменшення частки хворих із карциномами категорії T3-T4: 39,8\% (226/568), 33,1\% (338/1010), 20,0\% (364/1432) i 22,2\% (433/1946).

Із 1994 по 2000 рік збільшилася частота неметастазуючих папілярних карцином Щ3 (категорія N0 і M0) із подальшою стабілізацією цього показника. Щодо такої характеристики папілярних карцином Щ3, як інвазія в капсулу пухлини, зміни поширеності таких карцином не мали чіткої закономірності, а відсоток хворих із папілярними карциномами Щ3, які інвазують залозу або мають мультифокальний характер росту, зменшився лише за останній період спостереження. Водночас частка хворих із папілярними карциномами Щ3, які інвазують екстратиреоїдні структури, прогресивно зменшувалася починаючи вже з 2000 року (табл. 1). Отже, за 20 років спостереження серед хворих когорти 
спостерігали загалом зменшення частоти агресивніших папілярних карцином Щ3, хоча темпи цих змін за різними характеристиками були різними.

Зниження поширеності агресивніших папілярних карцином ЩЗ знайшло своє відображення в змінах структури клінічних показників хвороби: за період спостереження зросли частка хворих із I стадією хвороби та відсоток

таблиця 1. Динаміка змін поширеності папілярних карцином щитоподібної залози з різними характеристиками впродовж періоду спостереження, n (\%)

\begin{tabular}{|c|c|c|c|c|}
\hline \multirow[t]{3}{*}{ Показник } & \multicolumn{4}{|c|}{ Період спостереження, роки } \\
\hline & $\begin{array}{l}1995- \\
1999 \\
(n=568)\end{array}$ & $\begin{array}{l}2000- \\
2004 \\
(n=1010)\end{array}$ & $\begin{array}{l}2005- \\
2009 \\
(n=1432)\end{array}$ & $\begin{array}{l}2010- \\
2014 \\
(n=1946)\end{array}$ \\
\hline & 1 & 2 & 3 & 4 \\
\hline $\begin{array}{l}\text { Розмір пухлини } \\
\text { до } 10 \text { мм }\end{array}$ & $69(12,1)$ & $196(19,4)^{1}$ & $\begin{array}{l}410 \\
(28,6)^{1,2}\end{array}$ & $\begin{array}{l}843 \\
(43,3)^{1,2,3}\end{array}$ \\
\hline Категорія Т1-Т2 & $342(60,2)$ & $675(66,8)^{1}$ & $\begin{array}{l}1068 \\
(74,6)^{1,2}\end{array}$ & $\begin{array}{l}1513 \\
(77,8)^{1,2,3}\end{array}$ \\
\hline Категорія NO & $326(57,4)$ & $683(67,6)^{1}$ & $976(68,2)^{1}$ & $\begin{array}{l}1244 \\
(63,9)^{1,2}\end{array}$ \\
\hline Категорія M0 & $530(93,3)$ & $983(97,3)^{1}$ & $\begin{array}{l}1408 \\
(98,3)^{1}\end{array}$ & $\begin{array}{l}1918 \\
(98,6)^{1}\end{array}$ \\
\hline $\begin{array}{l}\text { Капсульна } \\
\text { інвазія }\end{array}$ & $477(84,0)$ & $932(92,3)^{1}$ & $\begin{array}{l}1263 \\
(88,2)^{1,2}\end{array}$ & $\begin{array}{l}1646 \\
(84,6)^{2,3}\end{array}$ \\
\hline $\begin{array}{l}\text { Інтратиреоїдна } \\
\text { інвазія }\end{array}$ & $346(60,9)$ & $652(64,6)$ & $862(60,2)^{2}$ & $\begin{array}{l}1061 \\
(54,5)^{1,2,3}\end{array}$ \\
\hline $\begin{array}{l}\text { Екстратиреоїд- } \\
\text { на інвазія }\end{array}$ & $190(33,5)$ & $272(26,9)^{1}$ & $\begin{array}{l}294 \\
(20,5)^{1,2}\end{array}$ & $\begin{array}{l}357 \\
(18,3)^{1,2}\end{array}$ \\
\hline $\begin{array}{l}\text { Мультифокаль- } \\
\text { ність }\end{array}$ & $128(22,5)$ & $202(20,0)$ & $252(17,6)^{1}$ & $339(17,4)^{1}$ \\
\hline $\begin{array}{l}\text { Стадія хвороби } \\
\text { । }\end{array}$ & $424(74,6)$ & $767(75,9)$ & $\begin{array}{l}1117 \\
(78,0)\end{array}$ & $\begin{array}{l}1561 \\
(80,2)^{1,2,3}\end{array}$ \\
\hline $\begin{array}{l}\text { Група дуже } \\
\text { низького } \\
\text { ризику }\end{array}$ & $68(12,0)$ & $171(16,9)^{1}$ & $\begin{array}{l}300 \\
(20,9)^{1,2}\end{array}$ & $\begin{array}{l}557 \\
(28,6)^{1,2,3}\end{array}$ \\
\hline $\begin{array}{l}\text { Група низького } \\
\text { ризику }\end{array}$ & $186(32,7)$ & $377(37,3)$ & $538(37,6)^{1}$ & $\begin{array}{l}541 \\
(27,8)^{1,2,3}\end{array}$ \\
\hline $\begin{array}{l}\text { Група високого } \\
\text { ризику }\end{array}$ & $314(55,3)$ & $462(45,7)^{1}$ & $\begin{array}{l}594 \\
(41,5)^{1,2}\end{array}$ & $848(43,6)^{1}$ \\
\hline РЙА & $360(63,4)$ & $807(79,9)^{1}$ & $\begin{array}{l}1148 \\
(80,2)^{1}\end{array}$ & $\begin{array}{l}1623 \\
(83,4)^{1,2,3}\end{array}$ \\
\hline 1 курс РЙТ & $40(7,0)$ & $57(5,6)$ & $114(8,0)^{2}$ & $113(5,8)^{3}$ \\
\hline 2 курси РЙТ & $40(7,0)$ & $57(5,6)$ & $114(8,0)^{2}$ & $113(5,8)^{3}$ \\
\hline $\begin{array}{l}3 \text { і більше кур- } \\
\text { сів РЙТ }\end{array}$ & $62(10,9)$ & $58(5,8)$ & $70(4,9)$ & $44(2,3)^{1,2,3}$ \\
\hline $\begin{array}{l}\text { MACIS: } \\
\text { до 5,99 бала }\end{array}$ & $459(80,8)$ & $870(86,1)$ & $\begin{array}{l}1271 \\
(88,8)^{1,2}\end{array}$ & $\begin{array}{l}1787 \\
(91,8)^{1,2}\end{array}$ \\
\hline 6-6,99 бала & $44(7,7)$ & $78(7,4)$ & $97(6,8)$ & $97(5,0)^{1,2,3}$ \\
\hline 7-7,99 бала & $30(5,3)$ & $35(3,5)$ & $35(2,4)^{1}$ & $35(1,8)^{1,2}$ \\
\hline понад 8 балів & $35(6,2)$ & $27(2,7)^{1}$ & $29(2,0)^{1}$ & $27(1,4)^{1,2}$ \\
\hline
\end{tabular}

Примітка: ${ }^{1,2,3}$ - вірогідна різниия з даними відповідної групи $\left(p_{x^{2}}<0,001\right)$. пацієнтів із дуже низьким ризиком рецидивів, але зменшилася частка хворих, які входили до груп низького та високого ризику. Зросла також частка хворих, яким було виконано РЙА, що зумовлено дотриманням протоколу проведення радіойодного лікування [19]. Натомість відсоток хворих, яким для одужання потрібно було проведення 3 і більше курсів РЙТ, зменшився за 20 років майже в 5 разів. Цю позитивну динаміку підтверджено і результатами аналізу прогнозу хвороби за системою MACIS (табл. 1).

3 огляду на вищенаведене останніми роками нами постійно вивчається та коригується протокол підготовки та проведення РЙД, РЙА та РЙТ. Основні особливості запропонованих змін до протоколу полягають у таких положеннях:

- Потрібно намагатися під час хірургічного лікування високодиференційованого раку ЩЗ досягати найповнішого видалення тканини залози з пухлиною та регіонарних метастазів, що дає змогу швидше досягти стійкого стану гіпотиреозу, необхідного для застосування радіойодного лікування, зменшити в майбутньому радіологічне навантаження на організм пацієнтів і прискорити процес їх реабілітації.

- За виконання зазначеної вище умови, за відсутності тиреоїдного залишку, час підготовки пацієнтів до РЙТ має не перевищувати 3 тижні. Незначний термін поопераційного гіпотиреозу суттєво не впливає та не погіршує самопочуття й загальний стан пацієнтів, а також перебіг супутніх захворювань (за їх наявності). Коротший термін вимушеного гіпотиреозу прискорює процес реабілітації пацієнтів після радіойодного сканування та дозволяє швидше досягти повноцінного евтиреоїдного стану (за рекомендаціями ATA, термін підготовки становить 3-4 тижні, ЕTA - 4-5 тижнів).

- Поопераційну візуалізацію з діагностичною дозою РФП показано пацієнтам із непоширеними формами високодиференційованого раку Щ3 (категорія рТ1-рТ2) без видимих (за результатами УЗД, операційними даними, результатами патогістологічної експертизи) метастатичних уражень (за протоколом ATA, поопераційне діагностичне сканування з радіоактивним йодом проводять лише у випадку невизначеності попереднього обсягу операції та стану захворювання). В інших випадках ми рекомендуємо застосовувати лі- 
кувальну дозу РФП (фахівці АТА лікувальні дози не рекомендують навіть для інтратиреоїдної пухлини розміром до 4 см або за наявності мікрометастазів папілярного раку в центральній групі лімфатичних вузлів).

- У випадках незначного накопичення РФП або цілковитої його відсутності за результатами проведення діагностичної процедури в ділянці шиї, «нульового» рівня онкомаркерів, відсутності патологічних змін у ділянці ЩЗ за даними поопераційного УЗД подальші радіологічні дослідження або РЙТ у пацієнтів із дуже низьким ризиком рецидивів проводити недоцільно.

- У разі підвищення рівнів тиреоглобуліну або антитіл до нього, наявності значної залишкової тканини залози, отримання даних про наявність метастазів або підозру на них потрібно проводити РЙА або/та РЙТ (за чинним протоколом).

Для оцінки доречності протоколу, що пропонується, ретроспективно проаналізовано результати обстеження пацієнтів із папілярними карциномами ЩЗ, яким після операції в рекомендовані терміни проведено РЙД або РЙА (табл. 2).

За результатами РЙД у 71\% пацієнтів із папілярними карциномами Щ3 категорії рТ1T2N0M0 або не виявлено накопичення РФП (рисунок), або воно було незначним (табл. 2). В інших пацієнтів для досягнення виліковування потрібно було проведення РЙА із застосуванням лікувальної дози РФП. За даними метааналізу, навіть для мікрокарцином частота віддалених метастазів становить $0,4 \%$ випадків, імовірність місцевого рецидиву $-2,5 \%$, а поширеність мікрометастазів у регіонарних лімфовузлах $-12-57 \%$ [17, 32, 33]. Слід також зазначити, що ефективність курсу РЙт збільшується після проведення першого низькодозового курсу РЙД [22, 34].

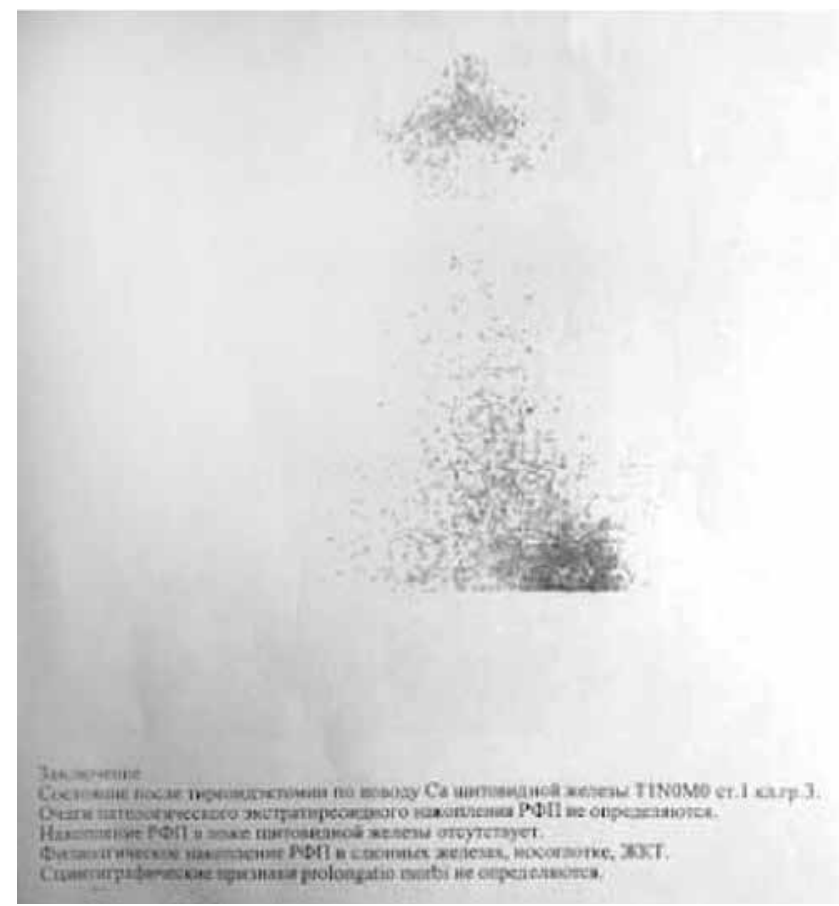

Рис. Сканограма хворого, якому проведено РЙД (140 мБк) із «нульовим» накопиченням РФП.

Результати визначення вмісту онкомаркерів у крові свідчать, що в пацієнтів із папілярними карциномами Щ3 категорії рT1-pT2N0M0 рівні тиреоглобуліну та антитіл до нього цілком відповідають факту відсутності накопичення РФП за даними сканування (табл. 2). У 2 пацієнтів із неметастазуючими папілярними карциномами Щ3 категорії рТ3 попри відсутність збільшення рівня онкомаркерів зафіксовано значне накопичення РФП у ділянці ложа ЩЗ. Більше ніж у половини хворих із метастазуючими папілярними карциномами Щ3 (N1a-N1ab) сканування виявило накопичення РФП і підвищення рівня онкомаркерів у крові.

Отже, цілком відмовитися від застосування абляції з використанням ${ }^{131} \mathrm{I}$ у пацієнтів України, які входять до груп дуже низького та низького ризику, як це рекомендують дослідники,

таблиця 2. Результати діагностичної або абляційної радіойодтерапії у хворих із папілярною карциномою щитоподібної залози, пролікованих за протоколом, що пропонується, n (\%)

\begin{tabular}{|c|c|c|c|c|c|c|c|}
\hline $\begin{array}{l}\text { Категорія карци- } \\
\text { номи }\end{array}$ & $\mathbf{n}$ & ТТГ, мг/мл & $\begin{array}{l}\text { Антитіла до } \\
\text { ТТГ, мг/л }\end{array}$ & $\begin{array}{l}\text { Відсутнє або не- } \\
\text { значне накопичен- } \\
\text { ня РФП }\end{array}$ & $\begin{array}{l}\text { Наявність } \\
\text { залишкової } \\
\text { тканини }\end{array}$ & $\begin{array}{l}\text { Отримували } \\
\text { лише діагнос- } \\
\text { тичну дозу РФП }\end{array}$ & $\begin{array}{l}\text { терапевтич- } \\
\text { ну дозу РФП }\end{array}$ \\
\hline T1-T2NOMO & 55 & $0,87 \pm 0,23$ & $20,6 \pm 2,0$ & $39(70,1)$ & $16(29,6)$ & $39(70,1)$ & $16(29,1)$ \\
\hline T1-T2N1a-N1abMo & 23 & $6,49 \pm 3,57^{*}$ & $23,5 \pm 5,0$ & $11(47,8)$ & $12(52,2)$ & $11(47,8)$ & $12(52,2)$ \\
\hline T3NOMO & 5 & $0,52 \pm 0,19$ & $20,0 \pm 0,0$ & $3(60,0)$ & $2(40,0)$ & $0(0,0)$ & $5(100)$ \\
\hline T3-T4N1a-N1abM0 & 15 & $7,38 \pm 3,85$ & $71,0 \pm 23,0^{*}$ & $5(33,3 \%)$ & $10(66,7 \%)$ & $0(0,0)$ & $15(100)$ \\
\hline
\end{tabular}

Примітка: * - вірогідна різниця з даними відповідної групи неметастазуючих карцином $\left(p_{u}<0,05\right)$. 
спираючись на результати власних сучасних досліджень [5-7], наразі ще не можна. Проте за виконання «чистої» тиреоїдектомії, що є важливою умовою [35], і дотримання вказаного вище протоколу, в понад двох третин хворих із неметастазуючими папілярними карциномами ЩЗ категорії pT1-pТ2 досить проведення лише РЙД, що цілком збігається з висновками інших авторів [9].

Отримані дані дозволять розробити та впровадити в практику персоніфіковану карту ведення пацієнтів із ДРЩЗ у перед- і поопераційний періоди. У кожному конкретному випадку потрібно визначати індивідуальний обсяг медичного та економічного навантаження. Це збігається з думкою інших дослідників: рекомендація щодо проведення РЙТ у пацієнтів із мікрокарциномою має грунтуватися на індивідуальному профілі ризику [36].

\section{Висновки}

Радикальне видалення щитоподібної залози з пухлиною є необхідною умовою для проведення хворим із папілярною карциномою низького ризику лише радіойод-діагностики без подальшої процедури радіойод-абляції. Водночас, зважаючи на українські реалії, цілком відмовитися від застосування абляції з використанням ${ }^{131} \mathrm{I}$ у пацієнтів України, які входять до групи з низьким ризиком (що є сучасним трендом у світовій тиреодології) наразі ще не можна.

\section{Список використаної літератури}

1. Haugen B, Alexander E, Bible K, Doherty G, Mandel S, Nikiforov Y, et al. 2015 American Thyroid Association Management Guidelines for Adult Patients with Thyroid Nodules and Differentiated Thyroid Cancer: The American Thyroid Association Guidelines Task Force on Thyroid Nodules and Differentiated Thyroid Cancer. Thyroid [Internet]. Mary Ann Liebert Inc; 2016; 26(1): 1-133.

2. Mahlangu N, Nyathi M. Protocol for differentiated thyroid cancer management at Dr George Mukhari Academic Hospital. AMJ. 2017; 10(9): 759-64.

3. Haymart M, Esfandiari H, Stang M, Sosa J. Controversies in the management of low-risk differentiated thyroid cancer. Endocrine Reviews. 2017;38(4): 351-78.

4. Jarząb B, Dedecjus M, Słowińska-Klencka D, Lewiński A, Adamczewski Z, Anielski R, et al. Guidelines of Polish National Societies diagnostics and treatment of thyroid carcinoma 2018 Update. Endokrynologia Polska. 2018; 69 (1): 34-74.

5. Lamartina L, Grani G, Durante C, Filetti S. Recent advances in managing differentiated thyroid cancer. F1000 Research. 2018; 7 (F1000 Faculty Rev): 86.

6. Sawka A, Ghai S, Tomlinson G, Rotstein L, Gilbert R, Gullane P, et al. A protocol for a Canadian prospective observational study of decisionmaking on active surveillance or surgery for low-risk papillary thyroid cancer. BMJ Open.2018; 8: e020298.

7. Asimakopoulos P, Nixon I. Surgical management of primary thyroid tumours. EJSO. 2018;44 (3): 321-6.
8. Ito Y, Miyauchi A, Kudo T, Oda H, Yamamoto M, Sasai H, et al. Trends in the implementation of active surveillance for low-risk papillary thyroid microcarcinomas at Kuma Hospital: Gradual increase and heterogeneity in the acceptance of this new management option. Thyroid. 2018; 28 (4):7.

9. Christakis I, Dimas S, Kafetzis I, Roukounakis N. Risk stratification of 282 differentiated thyroid cancers found incidentally in 1369 total thyroidectomies according to the 2015 ATA guidelines; implications for management and treatment. Ann R Coll Surg Engl. 2018; 100(5):357-65.

10. Wu D, Guan H. Letter to the Editor: «Decreasing use of radioactive iodine for low-risk thyroid cancer in California, 1999 to 2015». J Clin Endocrinol Metab. 2018; 103 (5): 2071-2.

11. Kuo S, Chao T, Chang H, Hsueh C, Yang C, Lin J. Prognostic evaluation of patients with multicentric papillary thyroid microcarcinoma. J Form Med Assoc. 2011;110 (8): 511-7.

12. Kusakabe K, Yokoyama K, Ito K, Shibuya H, Kinuya S, Ito M, et al. Thyroid remnantablation using 1,110 MBq of I-131 after total thyroidectomy: regulatory considerations on release of patients after unsealed radioiodine therapy. Ann Nucl Med. 2012;26 (4): 370-8.

13. Pacini F, Schlumberger M, Dralle H, Elisei R, Smit J, Wiersinga W European consensus for the management of patients with differentiated thyroid carcinoma of the follicular epithelium. Eur J Endocrinol. 2006;154 (6): 787-803

14. Yu X, Lloyd R, Chen H. Current treatment of papillary thyroid microcarcinoma. Adv Surg. 2012; 46: 191-203.

15. Mehanna H, Al-Maqbili T, Carter B, Martin E, Campain N, et al. Differences in the recurrence and mortality outcomes rates of incidental and nonincidental papillary thyroid microcarcinoma: A systematic review and meta-analysis of 21,329 person-years of followup. J Clin Endocrinol Metab. 2014; 99: 2834-43.

16. Armin M, Edge S, Greene F, Byrd D, Brookland R, Washington M, et al. AJCC Cancer staging manual, 8th ed.; Springer: New York, NY, USA. 2017; 1-19.

17. Perros P, Boelaert K, Colley S, Evans C, Evans R, Gerrard B, et al British Thyroid Association. Guidelines for the management of thyroid cancer. Clin Endocrinol. 2014; 81: 1-122.

18. Liu R, Bishop J, Zhu G, Zhang T, Ladenson P, Xing M. Mortality risk stratification by combining BRAF V600E and TERT promoter mutations in papillary thyroid cancer: genetic duet of BRAF and TERT promoter mutations in thyroid cancer mortality. JAMAOncol. 2017; 3 (2): 202-8.

19. Гулеватый СВ, Воскобойник ЛГ, Тронько НД. Применение радиойод терапии при дифференцированном раке щитовидной железы: международные стандарты и дискуссионные вопросы. Журнал НАМН України. 2013; 19 (3):339-54. (Gulevatiy SV, Voskoboynyk LG, Tronko ND. Application of radio-iodine therapy in differentiated thyroid cancer: international standards and debatable questions. Zhurnal NAMN Ukrayiny. 2013; 19 (3): 339-54)

20. Campennì A, Giovanella L, Pignata S, Vento A, Alibrandi A, Sturiale L, et al. Undetectable or low $(<1 \mathrm{ng} / \mathrm{ml})$ postsurgical thyroglobulin values do not rule out metastases in early stage differentiated thyroid cancer patients. Oncotarget. 2018; 9 (25): 17491-500.

21. Reiners Ch. Radio-iodine therapy in differentiated thyroid cancer: indications and procedures. Best Pract Res. 2008;22 (6): 989-1007.

22. Kukulska A, Krajewska J, Gawkowska-Suwińska M, Puch Z, PaliczkaCieslik E, Roskosz J, et al. Radioiodine thyroid remnant ablation in patients with differentiated thyroid carcinoma (DTC): prospective comparison of long-term outcomes of treatment with 30,60 and $100 \mathrm{mCi}$. Thyroid Res. 2010; 3(1): 9 .

23. Andresen N, Buatti J, Tewfik H, Pagedar N, Anderson C, Watkins J. Radioiodine ablation following thyroidectomy for differentiated thyroid cancer: Literature review of utility, dose, and toxicity. Eur Thyroid J. 2017; 6:187-96.

24. Bogdanova T, Zurnadzhy L, LiVolshi V, Williams D, Ito M, Nakashima M, et al. Thyroid cancer pathology in Ukraine after Chernobyl. In: Tronko M, Bogdanova T, Saenko V, Thomas G, Likhtarov I, Yamashita S, editors. Thyroid cancer in Ukraine after Chernobyl. Dosimetry, epidemiology, pathology, molecular biology. Nagasaki, Japan: mIN-TEX. 2014:65-108.

25. Nikiforov Y. Is ionizing radiation responsible for the increasing incidence of thyroid cancer. Cancer. 2010;116 (7): 1646-55.

26. Schonfeld S, Lee C, Berrington-De Gonzales A. Medical exposure to radiation and thyroid cancer. Clin Oncol. 2011; 23: 244-50. 
27. LiVolsi V, Abrosimov AA, Bogdanova TI, Fadda G, Hunt J, Ito M, et al. The Chernobyl thyroid cancer experience: pathology. Clin Oncol (R Coll Radiol). 2011;23 (4): 261-7.

28. Тронько МД, Богданова ТІ. Рак щитоподібної залози у дітей та підлітків України після аварії на Чорнобильській АЕС (епідеміологія, клінічні, патоморфологічні та молекулярно-генетичні аспекти). Журн НАМН України. 2011;17 (2): 139-43. (Tron'ko M Bogdanova T. Thyroid cancer in children and adolescents in Ukraine after the Chernobyl accident (epidemiology, clinical, pathologic and molecular genetic aspects). Zhurnal NAMN Ukrayiny. 2011; 17 (2): 139-43).

29. Gharib H, Papini E, Paschke R, Duick D, Valcavi R, Hegedüs L, et al. AACE/AME/ETA American Association of Clinical Endocrinologists, Associazione Medici Endocrinologi, and European Thyroid Association medical guidelines for clinical practice for thediagnosis and management of thyroid nodules. J Endocrinol Invest. 2010;33(5) (Suppl): 1-50

30. Болгов МЮ. Віддалені результати органозберігаючих операцій при високодиференційованих карциномах щитоподібної залози. Ендокринологія. 2009;14 (1): 21-6. (Bolgov MYu. Long-term results of organ-saving operations in highly differentiated carcinomas of the thyroid gland. Endokrynolohiya. 2009; 14 (1): 21-6)

31. Рыбаков СИ. Рак щитовидной железы: клинические лекции Полтава: ООО «АСМИ», 2012; 572 c. (Rybakov SI. Thyroid cancer: clinical lectures. Poltava: OOO «ASMI». 2012; 572 p.).

32. Gallicchio R, Giacomobono S, Capacchione D, Nardelli A, Barbato F, Nappi A, et al. Should patients with remnants from thyroid microcarcinoma really not be treated with iodine-131 ablation? Endocrine. 2013; 44: 426-33.

33. Avram A, Fig L, Frey K, Gross M, Wong K. Preablation 131-I scans with SPECT/CT in postoperative thyroid cancer patients: What is the impact on staging? J. Clin Endocrinol Metab. 2013; 98: 1163-71.

34. Fallahi B, Beiki D, Takavar A, Fard-Esfahani A, Gilani K, Saghari M, Eftekhari M. Low versus high radioiodine dose in postoperative ablation of residual thyroid tissue in patients with differentiated thyroid carcinoma: A large randomized clinical trial. Nucl Med Commun. 2012; 33: 275-82.

35. Kim H, Kim T, Choe J, Kim J, Kim J, Kim Y, et al. Surgeon volume and prognosis of patients with advanced papillary thyroid cancer and lateral nodal metastasis. Br J Surg. 2018; 105 (3): 270-8.

36. Dietlein M, EschnerW, Grünwald F, Lassmann M, Verburg F, Luster M Procedure guidelines for radioiodine therapy of differentiated thyroid cancer. Version 4. Nuklearmedizin. 2016; 55: 77-89.

(Надійшла до редакції 17.05.2019р.)

\section{Современные подходы к назначению радиойод- диагностики и радиойод-терапии больным, прооперированным по поводу папиллярной карциномы щитовидной железы}

\section{Б.Б. Гуда, С.В. Гулеватый, Н.Д. Тронько}

ГУ «Институт эндокринологии и обмена веществ им. В.П. Комиссаренко НАМН Украины»

Резюме. Цель - обосновать целесообразность назначения радиойод-диагностики и радиойод-терапии пациентам с папиллярными карциномами щитовидной железы (ЩЖ) из разных групп риска. Материал и методы. Анализировали данные когорты больных с папиллярными карциномами ЩЖ, которые получали комбинированное лечение в 1995-2014 годах (4956 лиц). Результаты. Частота папиллярных карцином ЩЖ с более агрессивными характеристиками (большой размер, наличие метастазирования, интра- или экстратиреоидной инвазии, мульфокальности) и бо- лее неблагоприятным течением (более високачя стадия болезни или группа риска, большее количество курсов радиойод-терапии, неблагоприятный прогноз по MACIS) среди больных когорты за 20 лет наблюдения уменьшилась. У 71\% больных с папиллярной карциномой ЩЖ категории рT1-рT2N0M0 по результатам диагностического сканирования накопление радиофармпрепарата отсутствовало или было незначительным. Выводы. Радикальное удаление ЩЖ с опухолью является необходимым условием для проведения больным с папиллярной карциномой ЩЖ очень низкого и низкого риска только радиойод-диагностики без дальнейшей процедуры радиойод-абляции. В то же время, учитывая украинские реалии, полностью отказаться от применения абляции с использованием ${ }^{131}$ । у пациентов Украины, которые входят в группу низкого риска (что является современным трендом в мировой тиреоидологии), пока нельзя.

Ключевые слова: папиллярная карцинома, радиойод-диагностика, радиойод-абляция.

Modern approaches for the determination of radioiddiagnostics and radioid-therapy in a patient with promoted of thyroid papillary carcinoma

\section{B.B. Guda, S.V. Gulevaty, M.D. Tronko}

State institution «V.P. Komisarenko Institute of Endocrinology and Metabolism, Nat. Acad. Med. Sci. of Ukraine»

Abstract. The purpose is to analyze the dynamics of the prevalence among patients with papillary carcinoma with different characteristics and clinical parameters of the disease, as well as to substantiate the expediency of assigning radioiodine diagnosis and radioiodine ablation in patients from different risk groups. Material and methods. Cohort of patients with papillary carcinomas, operated in 1995-2014 (4956 people) and patients who received radioiodine therapy in 2018 (98 people). Results. The frequency of papillary carcinoma with more aggressive characteristics (large size, presence of metastasis, intra-or extrathyroid invasion, multifocal) and more unfavorable course of disease (higher stage of disease and risk group, more number of courses of radioiodine therapy, poor prognosis for MACIS) among patients with cohort for 20 years of observation decreased. It was shown that in $71 \%$ of patients with papillary carcinoma of category PT1-pT2N0M0 in diagnostic scan there is no (or insignificant) accumulation of radiopharm drug. Conclusions. Radical removal of the thyroid gland with a tumor is a prerequisite for conducting patients with papillary carcinoma of very low and low risk only radioiodine diagnostics without further radioiodine ablation procedure. At the same time, taking into account Ukrainian realities, it is still not possible to completely refuse the use of ablation using ${ }^{131}$ I in patients in Ukraine who are part of the low-risk group, which is a modern trend in the world of thyroidology.

Keywords: papillary carcinoma, radioiodine diagnostics, radioiodine ablation. 